\title{
電気泳動法によるリチウム, ナトリウムイオンの連続分離
}

\author{
平井昭 司*, 垣 花 秀 武**

\begin{abstract}
Continuous Separation of Lithium and Sodium Ions by Electromigration
\end{abstract}

\author{
Shoji HiRAI* and Hidetake KAKIHANA**
}

\begin{abstract}
A new type of apparatus was used for the continuous separation of lithium and sodium ions. The apparatus consists of several compartments with ion-exchange membranes, and utilizes a combination of horizontal electromigration and vertical hydrodynamic movement. From compartment -2 (on the cathode side), concentrated sodium chloride was obtained continuously, and the separation factor seems to increase approximately in a hyperbolic relationship as the ratio of the countercurrent influx to the total effluxes of lithium and sodium ions moves from zero toward unity.
\end{abstract}

\section{1 緒 言(Introduction)}

1931 年 Prausnitz, Reitstötter ${ }^{1)}$ はイオン交換膜をイ オンの流れ方向に垂直に置く上，交換膜の選択性によ。 て陰, 陽イオンが分離されるであららと予想している。 その後 1950 年 $\mathrm{Juda}^{2)}, \mathrm{Kressman}^{3)}$ によって最初のイオ ン選抧性のあるイオン交換膜が製作され，電気透析の急 速なる進歩が開始された. しかしほとんどの研究は海水 の淡水化，または海水からの食塩の製造の研究であり， その原理は陽イオン交換膜が陽イオン, 陰イオン交換膜 が除イオンのみを選択的に透過することである。陽イオ ンどうしの分離については, Dewey Gilliland ${ }^{4)}$ が電気 透析ソウに蒸留塔の考えを導入し，ナトリウム，カリウ ムの分離を行なおうとしたが，収率が低く，電力消費が大 き過ぎるため, 工業的には不適当と判断し, その後の研 究は成されなかった。このよらな電気透析法の考えとは 別に，垣花 ${ }^{5)}$ らはイオン交換クロマトグラフィーの考え から出発して, その分離効果と電気泳動法の分離勃果を 組み合わせた装置を考案し, リチウム同位体の分離を行 なった，当初は装瞋に還流作用を加えずに分離を行なっ

* 武蔵工業大学原子力研究所 (川崎市多摩区王禅寺) Musashi Institute of Technology, Atomic Energy Research Laboratory (Ozenji, Tama-ku, Kawasaki, Kanagawa)

** 東京工業大学原子炉工学研究所 (東京都目黒区大岡山2-12 -1) Tokyo Institute of Technology, Research Laboratory for Nuclear Reactors (2-12-1, Ookayama, Meguro-ku, Tokyo)

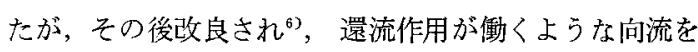
与え、リチウム同位体を分離した。しかしながら同位体 の分離效果注非常に小さく, 装置の特性を知るには困難 なことが多いので, 著者らはさらに装置を改良し分離効 果の大なリチウム，ナトリウムイオンの分離を行ない， 装置の特性一分離効果と向流の関倸一を研究し 報告す る.

\section{2 実 験(Experimental)}

\section{1 装}

分離装置本体の概略図を Fig. I に示寸．分離装置の 各要素は陰極側加陰極室, 溢出室, 向流供給室, 向流 側泳動室 (ナトリウムイオン濃縮室), 原液供給室, 原 液側泳動室 (リチウムイオン濃縮室)，陽極室の順にフ ィルタープレス状に横に並べられ構成されている，陰極 室と溢出室, 原液供給室と原液側泳動室との間には，そ れぞれ両側を多孔板で保持された陰イオン交換膜, その 他の要素の間には陽イオン交換膜で仕切りがなされてい る. 陰極室, 陽極室は塩化ビニル製の $16 \times 6 \times 1 \mathrm{~cm} の$ 大きさで，電極としてそれぞれ白金板と八ステロイ線を 使用している，溢出室はアクリル樹脂製で，16×6× $0.1 \mathrm{~cm}$ と非常に薄く, 分離されてきたナトリウムイオ ンをプロダクトとして取り出す室であり，容積を小さく するためにスペーサーが入れられてある. 向流供給室, 向流側泳動室, 原液供給室, 原液側泳動室はアクリル樹 脂製で，室の大きさは $16 \times 6 \times 0.5 \mathrm{~cm}$ である. 泳動室 は実験条件により，適宜，室の数を增減することができ 


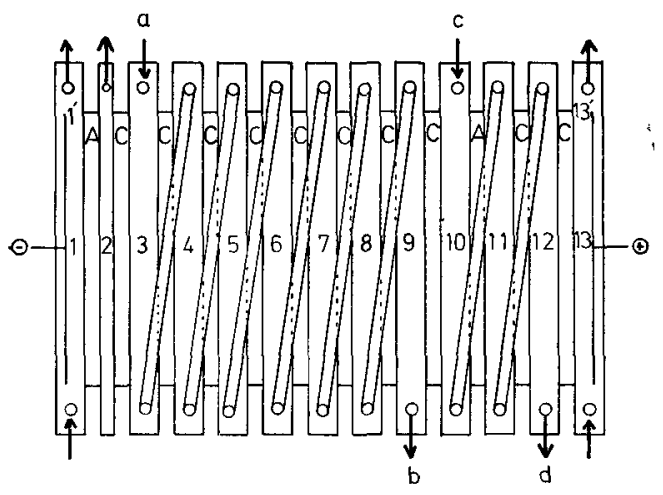

Fig. 1 Experimental apparatus

a : Countercurrent solution inlet

$\mathrm{b}$ : Countercurrent solution outlet

c : Feed solution inlet

$d$ : Feed solution outlet

A : Anion exchange membrane (CA-1)

$\mathrm{C}$ : Cation exchange membrane ( $\mathrm{CK}-1)$

Compartment

1: Cathode compartment $\left(1^{\prime}:\right.$ Pt-plate)

2: Compartment for accumulating sodium ions

3: Compartment for supplying countercurrent solution

4-9: Compartment for concentrating sodium ions

10: Compartment for supplying feed solution

11-12: Compartment for concentrating lithium ions

13: Anode compartment (13': hastelloy-wire)

る.この室の上下部の横に溶液の出入口が設けられ. 入 口，出口は塩化ビニル管によって連結されている. 試料 溶液は泳動室を水力学的に流れ, 一度室の出口加ら外に 出,塩化ビニル管を通ってふたたび㴹の室の人口に入り, 室の中を移動してゆく．分離装置全体のフローダイヤグ ラムを Fig. 2 に示す. 向流溶液, 原液ともマグネット ポンプ (イワキ製 MD50 あるいは MD 15) でへッド タンク $(4 \sim 5 \mathrm{~m})$ に持ち上げ, 向流供給室, 原液供給室 に流入させた。流速の調節はフローメーターでチェック しながら, 各出入口のスクリューコックによって行なっ た。陰極液，陽極液はそれぞれマグネットポンプ（MD 15）によって，極室と極液ソウの間を循環させた，泳動 電源として定電流電源 (昭和電子製) を用い, 電流は電 流計（横河製 0.5 級）で監視し，電圧は記録計（東冓電 液製 EPR-2 型) で連続記録を行なった。これら装置全 体は恒温室 $\left(25 \pm 2^{\circ} \mathrm{C}\right)$ の中に設置され, さらに分離装置 本体は空気恒温ソウ内に置かれ, 温度を一定 $(25.0 \pm$ $0.2^{\circ} \mathrm{C}$ ) 保った.

\section{2 試薬ならひににイオン交換膜}

$0.1 \sim 0.3 N$ 塩酸溶液を陰極液とし, 硫酸カリウム, 炭酸カリウム混合溶液 (陽極液ソウに炭酸カリウムの固 体を入れ，0.1 0.3N 硫酸カリウム溶液に飽和接触さ

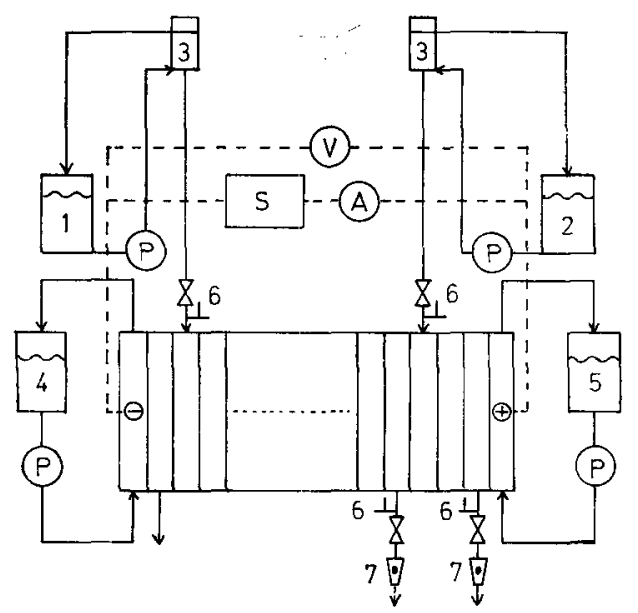

Fig. 2 Schematic diagram of experimental apparatus

1 : Countercurrent solution reservoir

$2:$ Feed solution reservoir

3 : Constant head tank

4: Catholyte tank

5 : Anolyte tank

$6:$ Thermometer

7 : Flow meter

A : Ampere meter

P : Pump

S : D.C. source

$\mathrm{V}:$ Voltage recorder

せた．これは陽極で発生した水素イオンを炭酸カリウム によって捕獲し，系内に水素イオンが泳動することを防 いでいる.）を陽極液として使用した。また $0.02 N$ 塩 酸溶液を向流溶液として, $0.1 N$ 塩化リチウム, 塩化ナ トリウム等容混合溶液を原液として使用した。これらの 試薬注塩化リチウム（和光純薬製 1 級）以外, 和光純薬 製特級試薬を用いた。陽イオン交換膜は地化成製 CK-1 交換膜をかみそりで, $22 \times 10 \mathrm{~cm}$ の大きさに切断し, 前 処理として約 $2 N$ 塩酸溶液で, 湯浴上にて 4 5 時間加 温した．その後純水で洗い，子たたび同じ操作をナトリ ウムイオンが検出されなくなるまで絽り返した。ナトリ ウムイオンの検出は炎色反応により定性的に行なった。 陰イオン交換膜は䢐化成製 CA-1 交換膜を陽イオン交 換膜々同じ大きさに切断し, 約 $2 N$ 水酸化ナトリウム 溶液で，陽イオン交換膜と同様な方法で前処理を行なっ た.

\section{3 実験条件ならび方法}

ナトリウム濃縮室 5 室とリチウム濃縮室 5 室ならびに ナトリウム穠縮室 7 室とリチウム濃縮室 2 室の二通りの 分離装置を組み立てた後, 装置内に陰極液, 陽極液, 原 液 ( $4 \sim 6 \mathrm{~m} l / \mathrm{min})$, 向流溶液 ( $3 \sim 7 \mathrm{ml} / \mathrm{min}$ 一定流速) を 流し, 定電流 $200 \mathrm{~mA}\left(2.1 \mathrm{~mA} / \mathrm{cm}^{2}\right)$ 電圧 $30 \sim 60 \mathrm{~V}$ で 
通電を開始した。通電後 1 日 2 回溢出室出口，向流出 口，原液出口の溶液を採取し，分析試料とした．分析の 結果，系がほぼ一定になったならば，向流流速を変えて 実験を継続した。また陰極液は 1 日に消費される電気量 に相当する塩酸量を每日 1 回補給し，陽極液は数日毎に 炭酸カリウム固体を補給した。

\section{4 分 析}

原液出口での試料はリチウム，ナトリウム，カリウム イオンの濃度分析を, 向流出口, 溢出室出口での試料は リチウム, ナトリウム, 水素イオンの濃度分析をした.

リチウム，ナトリウム，カリウムイオンの分析は，Varian-Techtron 製原子吸光光度計(炎光で使用)を用いて 測定した、リチウム，ナトリウム，カリウムイオンの測 定波長はそれぞれ $671,589,767 \mathrm{~nm}$ を，スリット幅は $0.2 \mathrm{~nm}$ を選んだ。水素イオンはフタル酸水素カリで標 定した水酸化ナトリウム溶液 $(0.10 N, 0.01 N)$ の標淮 溶液で，フェノールフタレンを指示薬として滴定した。

\section{3 結果および考察(Results and Discussion)}

向流出口ではカリウムイオンはまったく検出され ず*1，ナトリウム，リチウムつ組成比は原液の組成比々 ほとんど変らず，原液出口に杼いてはリチウムイオンが 多少濃縮したが，リチウム濃縮室の数が少くなかったた め，大きな分離効果は得られなかった. 溢出室出口にお いては，ナトリウムイオンが濃宿され，最む著しい分離 効果（原液組成比に対して約 8 倍）が得られたので，本 報文に扔いて主としてナトリウム濃縮に注目して考察す ることにする.

\section{1 向流流入量と流出量之の関係}

溢出室から流出してくるリチウムイオンとナトリウム イオンの量は，向流として流入する水素イオンの量と密 接な関係がある，単位時閒に向流として系内に流入する 水素イオンの量と単位時間に向流出口と溢出室から流出 するリチウムイオン，ナトリウムイオンの総量との比を 向流流入量比 $R$ と定義し，その $R$ を横軸とし，縦軸に 溢出空から流出してくるリチウム，ナトリウムイオンの 合計量をとり，Fig. 3 に示した。図から明らかなよう にほぼ一次の関倞があり，このことは系内の物質収支を 考えることにより理解される。

装置内の全体的なイオンの流れの様子を Fig. 4 に示 寸. 原液供給室-10 から陽イオン交換膜を透過して陰極 側に単位時間当り移動するリチウム，ナトリウムイオン の量を ${ }^{\circ} J_{10}{ }^{\mathrm{Li}},{ }^{0} J_{10}{ }^{\mathrm{Na}}$ 之L, 向流供給室-3保単位時間当り 流入する水素イオンの量を ${ }^{\mathrm{i}} I_{3}{ }^{\mathbf{H}}$ とする，また向流供給

*1 陽極液中のカリウムイオンはリチウム䟴縮室には検出され るが，Fig. 1 の10室と11茞の間の陰イオン交換膜によっ てさえぎら，向流出口より陰極側の室にはまったく移動 しない.

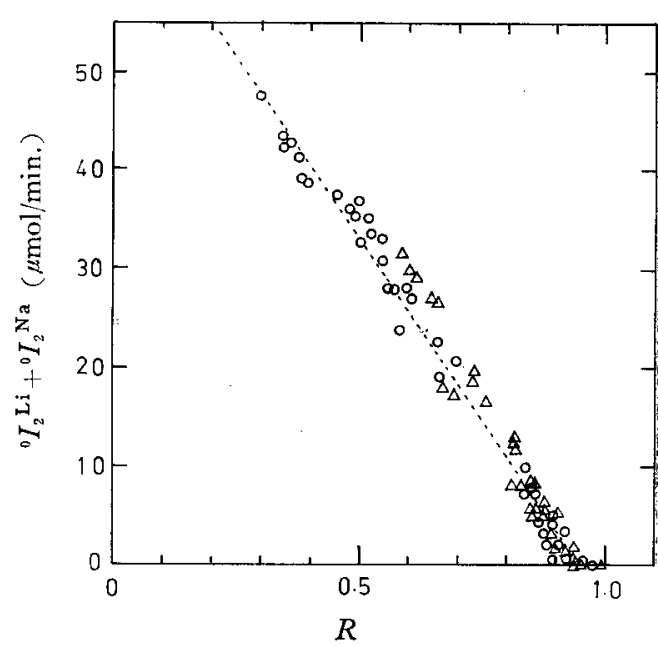

Fig. 3 Relationship between the effluxes of lithium and sodium ions from compartment -2 and $R$

- -5 compartments were used for concentrating sodium ions

$-\Delta^{-}: 7$ compartments were used for concentrating sodium ions

$R$ : The ratio of the countercurrent influx $\left({ }^{\mathrm{i}} I_{3}{ }^{\mathrm{H}}\right)$ to the total effluxes of lithium and sodium ions $\left({ }^{0} I_{2}{ }^{\mathrm{Li}}+{ }^{0} I_{2}{ }^{\mathrm{Na}}+{ }_{0} I_{9}{ }^{\mathrm{Li}}+{ }^{0} I_{9}{ }^{\mathrm{Na}}\right)$

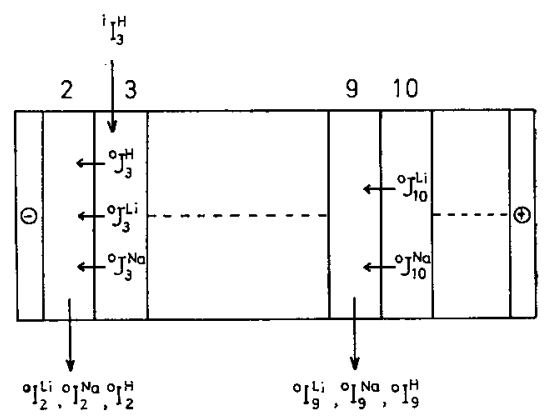

Fig. 4 The model of the overall ion flow in compartments for concentrating sodium ions

${ }^{\circ} I_{2}{ }^{\mathrm{Li}},{ }^{\circ} I_{2} \mathrm{Na},{ }^{\circ} I_{2}{ }^{\mathrm{H}}$ : Effluxes of lithium, sodium and hydrogen ions from compartment-2

${ }^{\mathrm{i}} I_{3}{ }^{\mathrm{H}}$ : Influx of hydrogen ions into compartment-3

${ }^{0} J_{3}{ }^{\mathrm{Li}},{ }^{0} J_{3}{ }^{\mathrm{Na}},{ }^{\mathrm{O}} J_{3}{ }^{\mathrm{H}}:$ : Effluxes of lithium, sodium and hydrogen ions into compartment-2 from compartment-3

${ }^{0} I_{9}{ }^{\mathrm{Li}},{ }^{\circ} I_{9} \mathrm{Na},{ }^{\circ} L_{9}{ }^{\mathrm{H}}$ : Effluxes of lithium, sodium and hydrogen ions from compartment-9

${ }^{0} J_{10} \mathbf{L i},{ }^{0} J_{10}{ }^{\mathrm{Na}}$ : Effluxes of lithium and sodium ions into compartment-9 from compartment-10 
室加ら陽イオン交換膜を透過し，溢出室に単位時間当り に集るそれぞれのイオン量を ${ }^{0} J_{3} \mathrm{H},{ }^{0} J_{3}{ }^{L i},{ }^{0} J_{3}{ }^{\mathrm{Na}}$ とし， 向流出口から単位時間に流出するそれぞれのイオン量を ${ }^{\circ} I_{9}{ }^{\mathrm{H}},{ }^{0} I_{9}{ }^{\mathrm{Li}},{ }^{\circ} I_{9} \mathrm{Na}$ とする。原液供給室と溢出室の間は多 くの陽イオン交換膜でさえぎられているので，電流はす ベて陽イオンによって運ばれるとすると，

$$
{ }^{0} J_{10}{ }^{\mathrm{Li}}+{ }^{0} J_{10}{ }^{\mathrm{Na}}={ }^{0} J_{3}{ }^{\mathrm{Li}}+{ }^{0} J_{3}{ }^{\mathrm{Na}}+{ }^{0} J_{3}{ }^{\mathrm{H}}=\eta I_{0}
$$

ここで $I_{0}$ は単位時間当りの電気量であり，クは電流効 率である. 溢出室に単位時閒当りに集るナトリウム, リ チウムイオンの合計量は (1) 式から

$$
{ }^{0} J_{3}{ }^{\mathrm{Li}}+{ }^{0} J_{3}{ }^{\mathrm{Na}}=\eta I_{0}-{ }^{0} J_{3}{ }^{\mathrm{H}}
$$

溢出室に入る量と出る量とが等しいとすると，

$$
{ }^{0} I_{2}{ }^{\mathbf{L i}}+{ }^{0} I_{2}{ }^{\mathrm{Na}}=\eta I_{0}-{ }^{0} I_{2}{ }^{\mathbf{H}}
$$

水素イオンについての物質収支から

$$
{ }^{\mathrm{i}} \boldsymbol{I}_{3}{ }^{\mathrm{H}}={ }^{0} I_{2}{ }^{\mathrm{H}}+{ }^{0} I_{9}{ }^{\mathbf{H}}
$$

$$
\begin{aligned}
& \left(2^{\prime}\right),(3) \text { 式加方 } \\
& { }^{0} I_{2}{ }^{\mathrm{Li}}+{ }^{0} I_{2}{ }^{\mathrm{Na}}=\eta I_{0}-{ }^{\mathrm{i}} I_{3}{ }^{\mathrm{H}}+{ }^{\circ} I_{9}{ }^{\mathrm{H}}
\end{aligned}
$$

ここで ${ }^{0} I_{9}{ }^{\mathrm{H}}$ が ${ }^{\mathrm{i}} I_{3}{ }^{\mathrm{H}}$ に比べて非常に小さい場合，(4)式 は次式のよ5に近似できる。

$$
{ }^{0} I_{2}{ }^{\mathrm{Li}}+{ }^{\mathrm{O}} I_{2}{ }^{\mathrm{Na}} \fallingdotseq \eta I_{0}-{ }^{\mathrm{i}} I_{3}{ }^{\mathrm{H}}=\eta I_{0}\left(1-{ }^{\mathrm{i}} I_{3}{ }^{\mathrm{H}} / \eta I_{0}\right)
$$

すなわち溢出空からのリチウムイオンとナトリウムイオ

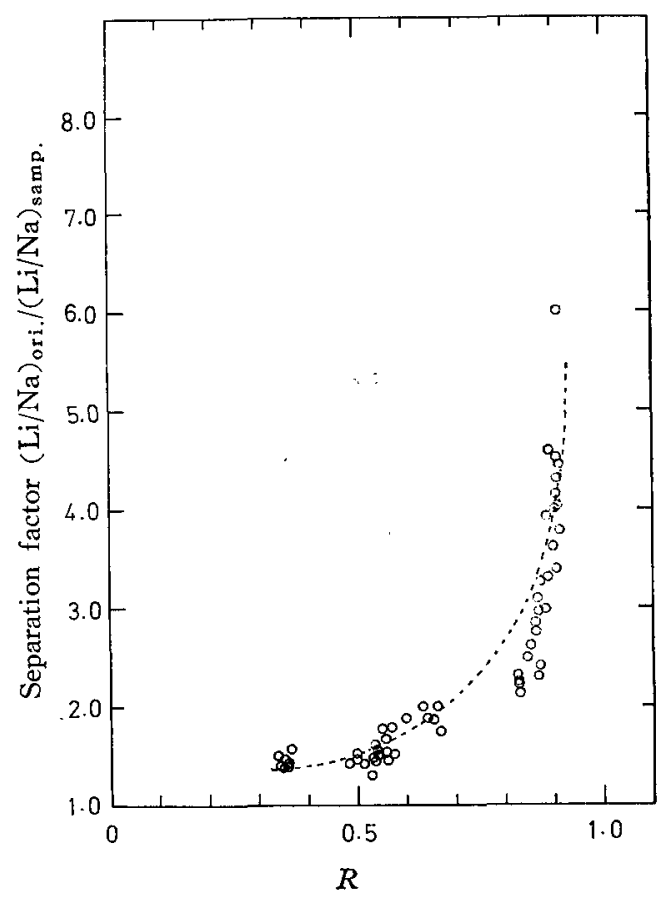

Fig. 5 Relationship between the separation factor and $R$ (the ratio of the countercurrent influx to the total effluxes of lithium and sodium ions)

In this experiment, 5 compartments were used for concentrating sodium ions
ンとの流出量の和は, 系内に電気的に流人する全イオン 量と向流で系内に入る水素イオン量との差に相当する

(これを向流の押し戻し作用と呼ぶ）。またナトリウム イオンとリチウムイオンの物質収支が，

$$
\begin{aligned}
& { }^{0} J_{\mathrm{L} 0}{ }^{\mathrm{Na}}={ }^{0} I_{2}{ }^{\mathrm{Na}}+{ }^{0} I_{9} \mathrm{Na} \\
& { }^{0} J_{10}{ }^{\mathrm{Li}}={ }^{0} I_{2}{ }^{\mathrm{Li}}+{ }^{0} I_{9}{ }^{\mathrm{Li}}
\end{aligned}
$$

(1)，(6)，(7) 式加占

$$
\eta I_{0}={ }^{0} I_{2}{ }^{\mathrm{Li}}+{ }^{0} I_{2}{ }^{\mathrm{Na}}+{ }^{0} I_{9}{ }^{\mathrm{Li}}+{ }^{0} I_{9} \mathrm{Na}
$$

したがって先に述べた向流流入量比は

$$
R={ }^{\mathrm{i}} I_{3}{ }^{\mathrm{H}} /{ }^{0} I_{2}{ }^{\mathrm{Li}}+{ }^{0} I_{2}{ }^{\mathrm{Na}}+{ }^{0} I_{9}{ }^{\mathrm{Li}}+{ }^{0} I_{9}{ }^{\mathrm{Na}}={ }^{\mathrm{i}} I_{3}{ }^{\mathrm{H}} / \eta I_{0} \text { (9) }
$$

よって (9) 式から（5）式は

$$
{ }^{0} I_{2}{ }^{\mathrm{Li}}+{ }^{\circ} I_{2}{ }^{\mathrm{Na}}=\eta I_{0}(1-R)
$$

Fig. 3 から明らかなように本系はほぼ（5') 式に従って いる.この事実は本実験に拧いて物質収支が保持され， 先に述べた仮設 ${ }^{0} I_{9}{ }^{\mathrm{H}} \approx 0$ 汸不合理でない系，すなわち水 秦イオンがリチウム，ナトリウムイオンのバンドを追い 越して，陽極側方向に行くことが少くなく，いわゆる置 換クロマトグラフィーに近い状態が依持されていること を示している。

\section{2 向流流入量比と分離係数}

溢出室から流出してくろナトリウムイオンとリチウム

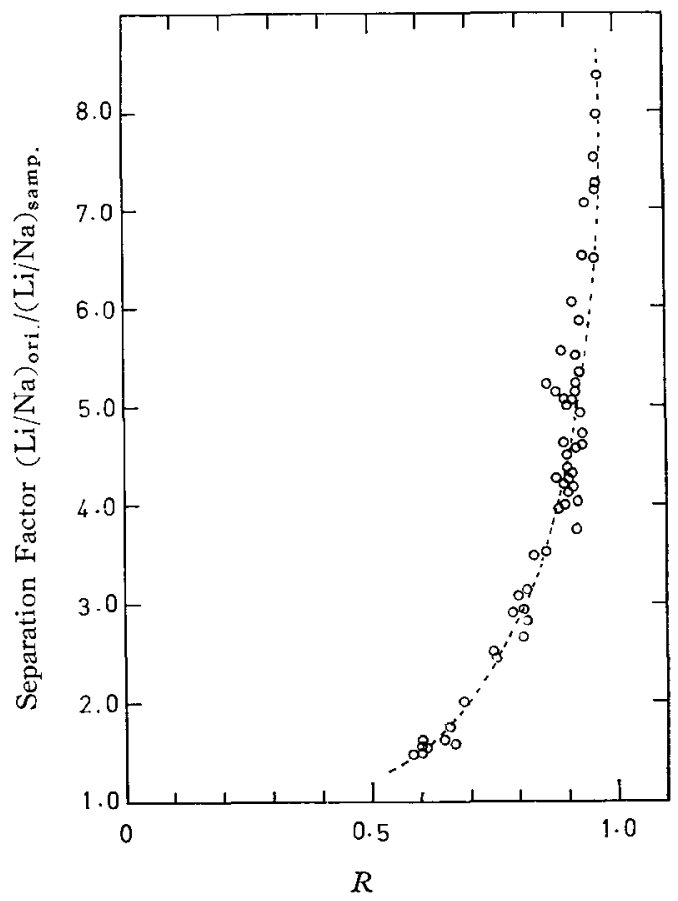

Fig. 6 Relationship between the separation factor and $R$ (the ratio of the countercurrent influx to the total effluxes of lithium and sodium ions)

In this experiment, 7 compartments were used for concentrating sodium ions 
イオンのモル比と原液のモル比との比（分離係数）を向 流流入量比に関してプロットすると Fig. 5, Fig. 6 の ような関係が得られる. 向流流入量比が 0 から 1 に近ゔ くにつれて, 分離係数は增大寸る. 1 を越えると当然の ことながら，溢出室から注ナトリウム，リチウムイオン は流出してこなくなる.

3.2.1 速度分布一次元場においてイオンが両極間 を一定電場を受けて泳動するとき，個々のイオンの泳動 速度は一定でなく，拡散や流れの場等の影響で泳動速度 は，一つの分布（通常は正規分布）を持っている. 同様 にイオンを電場でなく，水力学的な流れを与えた場合に も，イオンの流れ速度は分布を持つ.このような二つの 流れの要素 ( $\mathrm{X}$ 軸に泳動の流れ, $\mathrm{Y}$ 軸に水力学的流れ) を二次元場に扔いた場合，1個のイオンの動きは，Fig. 7 の $\overrightarrow{\mathrm{OA}}$ で示されるような泳動で流れる力と水力学的 に流れる力との釣り合いによって, ベクトル和で移動す る.しかしながらイオン全体については上述したように 個々のイオンの流れ速度に分布を持っているので，Fig. 7 の鎖線で示されるような分布をする。この錤線は同一 頻度の速度分布の等高線である.ここで第一のイオン $\mathrm{A}$ とは別の異種の第二のイオン $\mathrm{B}$ 同一場に置いたとき, イオン種によって場からの力の受け方が異なり, Fig. 7 に示したよらに，A，B イオン種は違った分布の仕方を する. 分布の頻度の山が $\mathrm{A}, \mathrm{B}$ 異なって現れてくるこ とは, $\mathrm{A}, \mathrm{B}$ 二種のイオンが一定の場の力によって分離 されることを意味する。

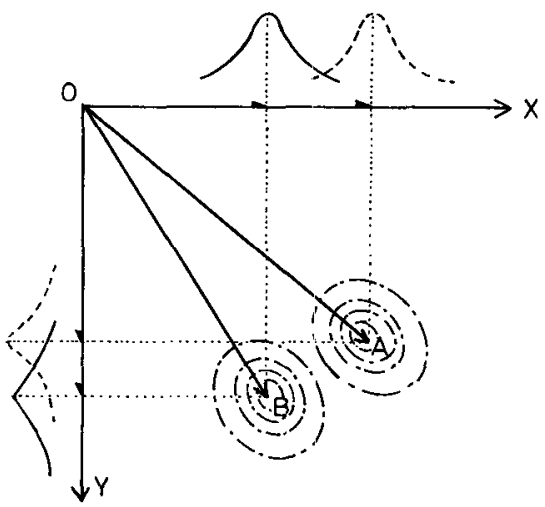

Fig. 7 A pattern for the flows of two different ions

3.2 .2 分離機構 今まで述べてきたようにそれぞ れのイオンの速度は分布を持っているので, イオンの動 きを正確に解析するのは、はなはだ困難である.しかし分 布の頻度の最高值 (Fig. 7 の $\overrightarrow{\mathrm{OA}}$, または $\overrightarrow{\mathrm{OB}}$ )をイオ ン種の代表速度とすると，イオンの動きを単純なモデル (Fig. 8) で考えることができる. 今 $j$ (リチウムあるい はナトリウム) イオンが $n$ 番目の境界（イオン交換膜）

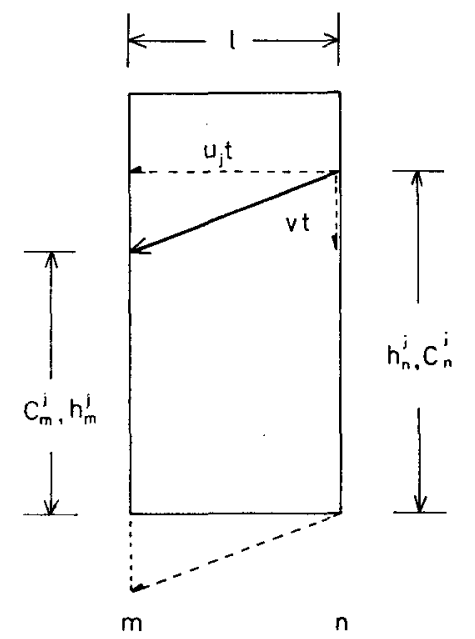

Fig. 8 Simplified model of $j$-ion flow

$j:$ Lithium or sodium ion

$n, m$ : Boundary (ion-exchanger)

$h_{\mathrm{n}}{ }^{\mathrm{j}}$ : Height of $j$-ion at $n$-boundary

$C_{\mathrm{n}}{ }^{j}$ : Concentration of $j$-ion at $n$-boundary

$u_{\mathrm{j}}$ : Electromigration velocity of $j$-ion

$v:$ Hydrodynamic velocity

$l:$ Migration length

$t:$ Time

から $m$ 番目の境界に向って移動すると考える. その際 $j$ イオンは図に示したように濃度 $C_{\mathrm{n}}{ }^{\mathrm{j}}$, 高さ $h_{\mathrm{n}}{ }^{\mathrm{j}}$ で移動 を開始し, 電気泳動による水平方向の移動速度 $u_{\mathrm{j}}$ で $t$ 時 間後に $l$ た移動して， $m$ の境界に達し，その間に垂直 方向の速度 (向流速度) vで vt の距離下方に移動する $\varepsilon, m$ の境界で $j$ イオンの存在し得る高さは，

$$
h_{\mathrm{m}}{ }^{\mathrm{j}}=h_{\mathrm{n}}{ }^{\mathrm{j}}-v t=h_{\mathrm{n}}{ }^{\mathrm{j}}-v\left(l / u_{\mathrm{j}}\right)=h_{\mathrm{n}}{ }^{\mathrm{j}}\left(1-v / u_{\mathrm{j}} \cdot l / h_{\mathrm{n}}{ }^{\mathrm{j}}\right)
$$

濃度 $C$ と高さ $h$ との間に一次的な比例関倸が成り立つ とすると，

$$
C_{\mathrm{m}}{ }^{\mathrm{j}}=C_{\mathrm{n}}{ }^{\mathrm{j}}\left(1-v / u_{\mathrm{j}} \cdot l / h_{\mathrm{n}}{ }^{\mathrm{i}}\right)
$$

$m$ の境界から単位時間に流出するリチウム，ナトリウム イオンの流出量は (11) 式加ら

$$
\begin{aligned}
& { }^{0} J_{\mathrm{m}}{ }^{\mathrm{Li}}=C_{\mathrm{m}}{ }^{\mathrm{Li}_{\mathrm{i}}} u_{\mathrm{Li}}=C_{\mathrm{n}}{ }^{\mathrm{Li}} u_{\mathrm{Li}}\left(1-v / u_{\mathrm{Li}} \cdot l / h_{\mathrm{n}}{ }^{\mathrm{Li}}\right) \\
& { }^{0} J_{\mathrm{m}}{ }^{\mathrm{Na}}=C_{\mathrm{m}}{ }^{\mathrm{Na}} u_{\mathrm{Na}}=C_{\mathrm{n}}{ }^{\mathrm{Na}} u_{\mathrm{Na}}\left(1-v / u_{\mathrm{Na}} \cdot l / h_{\mathrm{n}}{ }^{\mathrm{Na}}\right)
\end{aligned}
$$

今 $m$ 在溢出室にでる境界, $n$ を陽極方向から系内に入 る境界とすると, 溢出室に打沙る分離係数 $\alpha$ は，(12), (13) 式より次式のように得られる.

$$
\begin{aligned}
\alpha & =\left({ }^{0} J_{\mathrm{m}}{ }^{\mathrm{Na} /} / J_{\mathrm{m}}{ }^{\mathrm{Li}}\right) /\left(C_{\mathrm{n}}{ }^{\mathrm{Na}} / C_{\mathrm{n}}{ }^{\mathrm{Li}}\right) \\
& =\left(u_{\mathrm{Na}}-v l / h_{\mathrm{n}}{ }^{\mathrm{Na}}\right) /\left(u_{\mathrm{Li}}-v l / h_{\mathrm{n}}{ }^{\mathrm{Li}}\right)
\end{aligned}
$$

(14) 式の分子, 分母に向流溶液の水素1オン濃度 ${ }^{{ }^{i}} C_{3}{ }^{H}$ をかけ（8）式と $R$ を用いて変形すると 


$$
\begin{aligned}
\alpha & =\left\{{ }^{\mathrm{i}} C_{3}{ }^{\mathrm{H}} u_{\mathrm{Na}}-\eta I_{0}\left(l / h_{\mathrm{n}}{ }^{\mathrm{Na}}\right) R\right\} /\left\{{ }^{\mathrm{i}} C_{3}{ }^{\mathrm{H}} u_{\mathrm{Li}}\right. \\
& \left.-\eta I_{0}\left(l / h_{\mathrm{n}}{ }^{\mathrm{Li}}\right) R\right\}
\end{aligned}
$$

となる.Fig. 5, Fig. 6 亿おいてほぼ双曲線汇近い関係 湆得られているが，本実験においては，溢出室にでる境 界面と系内に入る境界面との間は多数のイオン交换膜で 仕切られ，還流作用妿働いているが，全体として近似的 に上に述べたようなイオンの動きが推論できよう。

\section{3 室の数と分離保数}

Fig. 5 はナトリウムイオンを濃縮する室が 5 室（向流 “供給室と向流側泳動室 4 室)，Fig. 6 注 7 室の場合であ り，分離効果は 7 室の方が大きく現れている。このこと は室の数が多くなればそれだけ泳動距離（し）が長くな り，同じ操作条件で運転を行なえば，(15)式から明らか なように分離効果も当然增大する。

\section{4 結 論(Conclusion)}

以上のことを要約すると次のようになる。

(1) 向流流入量比と溢出室加流出してくるリチウ
ムイオンとナトリウムイオンの合計量はほぼ一次の関係 が成り立ち，このこと加ら本系は置換クロマトグラフィ 一に近、関倸と推論できる。

（2）分離係数は向流流入量比が 1 に近ぶく还、， 双曲線的増大寸る。

（3）室の数を増すことにより，分離効果は増大す る.

（4）本実験によって溢出室より濃縮した塩化ナトリ ウムを連続的に取り出されることが明らかになった。

$<$ 1487> (Received Jan. 24, 1975)

$$
\text { 文献 }
$$

1) P.H. Prausnitz, J. Reitstötter, "Elektrophorse, Elektro-osmose, Elektrodialyse", Theodor Steinkopff, Dresden, (1931).

2) W. Juda, W.A.J. Mcrae, J. Amer. Chem. Soc. $\mathbf{7 2 ,}$ 1044 (1950).

3) T.R.E. Kressman, Nature 165, 568 (1950).

4) D.R. Dewey, E.R. Gilliland, U.S. Pat. 2,741,591.

5）垣花秀武，森 芳弘，星野忠也，J. Atomic Energy Sac. Japan 6, 65 (1964).

6) 岡本真実, 学位論文 (東京工大) (1966). 